\title{
MODIFIKASI TEPUNG BIJI NANGKA (Arthocarphus heterophyllus lamk) DENGAN METODE ASETILASI
}

\author{
Mey Sulistiyaningsih", Laeli Kurniasari dan Farikha Maharani \\ Jurusan Teknik Kimia, Fakultas Teknik, Universitas Wahid Hasyim \\ Jl. Menoreh Tengah X/22, Sampangan, Semarang 50236. \\ "Email: mey.sulistiyaningsih@yahoo.co.id
}

\begin{abstract}
Abstrak
Pemanfaatan biji nangka (Arthocarphus heterophyllus lamk) sebagai bahan baku dalam produksi makanan memiliki keterbatasan berkaitan dengan sifat fisikokimia tepungnya. Asetilasi merupakan salah satu metode modifikasi tepung yang dapat digunakan untuk meningkatkan sifat fisikokimia tepung, yakni swelling power, \% solubility, dan derajat substitusi. Penelitian ini bertujuan untuk mengetahui pengaruh konsentrasi asam asetat (5\%, $10 \%, 15 \%)$, waktu (10 menit dan 30 menit), dan suhu $\left(55^{\circ} \mathrm{C}, 65^{\circ} \mathrm{C}, 75^{\circ} \mathrm{C}\right)$ terhadap nilai swelling power, \% solubility, dan derajat substitusi tepung biji nangka terasetilasi. Biji nangka yang sudah menjadi tepung, diproses secara asetilasi, lalu hasilnya di uji untuk mengetahui tepung yang memiliki kualitas lebih baik. Dari percobaan diperoleh hasil kondisi optimal pada pati yang dimodifikasi dengan konsentrasi $5 \%$, suhu $55^{\circ} \mathrm{C}$, dan waktu reaksi 10 menit, dengan nilai swelling power $7,40 \mathrm{~g} / \mathrm{g}$, solubility $9 \%$, dan derajat substitusi sebesar 2,34.
\end{abstract}

Kata kunci : biji nangka, asetilasi, swelling power, \% solubility, derajat substitusi

\section{PENDAHULUAN}

Tanaman nangka merupakan jenis tanaman tropis, sehingga cocok untuk ditanam di Indonesia. Biji nangka selama ini jarang dimanfaatkan. Salah satu cara pemanfaatan biji nangka adalah mengolahnya menjadi tepung. Penggunaan biji nangka cukup menguntungkan, mengingat harganya yang relatif murah dan mudah didapat (Ibrahim dkk, 2014). Tepung biji buah nangka dapat diolah lebih lanjut menjadi berbagai macam produk seperti dodol, kerupuk, snack dan juga biskuit (Kurniawati. 2015).

Biji nangka mengandung berbagai komponen diantaranya protein $4,2 \%$, karbohidrat $36,7 \%$, serat $2,74 \%$, lemak $0,1 \%$. Selain itu biji tersebut juga mengandung zat gizi lain seperti kalsium, fosfor, besi, vitamin B1, dan Vitamin C (Ma'rufah, 2016).

Produksi tepung biji nangka rata-rata menghasilkan rendemen sebesar $65 \%$. Nilai ini berarti dari $100 \mathrm{~g}$ biji nangka akan dihasilkan $65 \mathrm{~g}$ tepung. Sejak jaman dahulu, tepung umbiumbian telah banyak banyak digunakan untuk produksi berbagai macam produk. Produkproduk olahan tepung itu diantanya berfungsi sebagai penstabil, pengental, pemberi tekstur, pembentuk film dan gel, bahan enkapsulan, menjaga kelembaban dan memperpanjang umur simpan. Tepung juga dapat berfungsi untuk menjaga kelembaban pada makanan panggang, sebagai zat anticaking pada baking powder dan media pembentuk pada permen. Sifat fisik dan kimia tepung alami, umumnya masih kurang sesuai apabila digunakan secara luas. Oleh karenanya pemanfaatan tepung alami masih sangat terbatas. Hal ini memunculkan ide untuk melalukan proses modifikasi agar diperoleh tepung dengan sifat-sifat yang dikehendaki dan lebih tahan terhadap air (Amalia dkk, 2016)

Modifikasi tepung dapat dilakukan secara kimia dan fisika untuk menghasilkan produk pangan ramah lingkungan (Parwiyanti, 2011) Modifikasi dapat pula dilakukan secara enzimatik untuk meningkatkan sifat fungsional yang diinginkan. Salah satu modifikasi tepung secara kimia adalah modifikasi dengan asetilasi. Melalui proses ini akan dihasilkan tepung asetat. Proses modifikasi dilakukan dengan esterifikasi tepung alami dengan asam asetat. Adanya gugus asetil yang masuk ke dalam tepung akan mengurangi kekuatan ikatan diantara molekul tepung yang berakibat pada peningkatan daya kembang serta kelarutan. Aplikasi tepung asetat pada berbagai macam produk pangan diantaranya adalah produk makanan yang dipanggang, isian pie, saus, sup, makanan beku, makanan bayi, salad dressing, dan makanan ringan (Amalia dkk, 2016).

\section{METODOLOGI}

\section{Bahan dan Alat Penelitian}

Pada penelitian ini digunakan biji nangka yang dibeli dari Pasar Karang Ayu, Semarang, Jawa Tengah. Bahan lainnya adalah kertas $\mathrm{pH}$, 
Aquadest, Asam asetat, $\mathrm{NaOH}, \mathrm{HCl}, \mathrm{KOH}$, Etanol, dan Indikator PP.

Peralatan yang digunakan untuk modifikasi tepung biji nangka adalah aliran air kran, magnetik stirer, thermometer, statif klem, kompor listrik, labu leher tiga, cawan petri, timbangan, gelas ukur, beaker glass, erlenmeyer, corong, pisau, blender, ayakan. Penelitian dilakukan di Laboratorium Proses Jurusan Teknik Kimia Universitas Wahid Hasyim Semarang.

\section{Prosedur dan Langkah Penelitian Pembuatan Tepung Biji Nangka}

Biji nangka dicuci selama 10 menit, setelah itu direbus sampai 30 menit dan tiriskan, selanjutnya kulit luar dan kulit arinya dikupas, Setelah bersih dari kulitnya, biji dipotong 6-8 bagian lalu ditata diatas tampah yang dilapisi plastik bening, selanjutnya biji keringkan dibawah terik panas matahari selama 2 hari, biji nangka yang sudah kering ditumbuk lalu di blender sampai halus, tepung biji nangka diayak dengan ayakan 100 mesh (Rohmah, 2013), tepung biji nangka siap untuk diuji.

\section{Proses Asetilasi :}

Lima belas gram tepung biji nangka direndam dalam $100 \mathrm{~mL}$ aquades untuk memudahkan proses pencampuran tepung dengan reagen asam asetat, penambahan larutan asam asetat (5,10 dan 15$) \% \mathrm{~V}$ dan larutan $\mathrm{NaOH} 1 \mathrm{~N}$ secara simultan ke dalam larutan tepung, $\mathrm{pH}$ larutan selama reaksi antara 8-8,4, selanjutnya diberi panas sampai suhu mencapai variabel yang ditetapkan yaitu $55^{\circ} \mathrm{C}, 65^{\circ} \mathrm{C}$ dan $75^{\circ} \mathrm{C}$, setelah selang waktu reaksi sesui variabel (10 dan 30 menit) tercapai, larutan $\mathrm{HCl} 1 \mathrm{~N}$ ditambahkan sampai $\mathrm{pH}$ nya 6 , slurry pati kemudian difiltrasi dan hasil endapannya dicuci 3 kali dengan aquades sampai pH nya 7 (palupi, 2013). Endapan tepung kemudian dikeringkan pada suhu $50^{\circ} \mathrm{C}$ sampai diperoleh moisture content yang konstan.

\section{Teknik Analisis}

\section{Analisis Derajat Substitusi}

Analisis Derajat Substitusi mengikuti prosedur dari Amalia dkk, (2016). Tepung terasetilasi ditimbang sebanyak 1 gram dan dilarutkan dalam $50 \mathrm{~mL}$ etanol pada suhu $50{ }^{\circ} \mathrm{C}$ selama 30 menit. Slurry tepung didinginkan pada suhu ruang, ditambahkan $40 \mathrm{~mL} \mathrm{KOH} \mathrm{0,5}$ M. Excess alkali dititrasi dengan $0,5 \mathrm{M} \mathrm{HCl}$ dengan menggunakan indikator phenolphthalein. Kadar asetil dihitung dengan persamaan (1) sedangkan Derajat Substitusi (DS) dihitung dengan persamaan (2).

$\%$ Asetil $=\frac{((V o-V n) \times N) \times 0,043 \times 100}{M}$

dimana:

$\mathrm{Vo}=$ volume $\mathrm{HCl}$ untuk titrasi blanko

$\mathrm{Vn}=$ volume $\mathrm{HCl}$ untuk sampel

$\mathrm{M}=$ massa sampel kering

$\mathrm{DS}=\frac{162 \times \% \text { Asetil }}{4300-(42 \times \% \text { Asetil })}$

\section{Analisisa Swelling Power}

Analisis swelling power (Amalia dkk, 2016). dilakukan dengan melarutkan 0,1 gram tepung terasetilasi dalam $10 \mathrm{ml}$ aquadest dan dipanaskan menggunakan water bath dengan temperatur $60{ }^{\circ} \mathrm{C}$ selama 30 menit. Kemudian dicentrifuge dengan kecepatan $2500 \mathrm{rpm}$ selama 15 menit untuk memisahkan supernantant dan pasta yang terbentuk. Swelling power dihitung dengan rumus sesuai persamaan (3)

Swelling power $=\frac{\text { Berat pasta }}{\text { Berat sampel kering }}$

\section{Analisisa \% Solubility}

Untuk analisis \% solubility (Amalia dkk, 2016), 0,1 tepung terasetilasi dilarutkan dalam $10 \mathrm{ml}$ aquadest dan dipanaskan dalam water bath dengan temperatur $60{ }^{\circ} \mathrm{C}$ selama 30 menit. Kemudian dicentrifuge dengan kecepatan 2500 rpm selama 15 menit untuk memisahkan supernantant dan pasta yang terbentuk. Supernantant diambil sebanyak $10 \mathrm{ml}$ lalu dikeringkan dalam oven dan dicatat berat endapan keringnya. Persen solubility dihitung dengan persamaan (4).

$\%$ Solubility $=\frac{\text { Berat endapan kering }}{\text { Berat sampel }} \times 100 \%$ (4) 


\section{HASIL DAN PEMBAHASAN}

\section{a. Uji Derajat Substitusi}

Nilai derajat substitusi pada penelitian ini diuji berdasarkan waktu reaksi, pengaruh konsentrasi asam asetat dan suhu reaksi. Peningkatan jumlah asam asetat menyebabkan penurunan derajat substitusi, hal ini dapat dilihat pada gambar 1 yang menunjukkan bahwa konsentrasi asam asetat sebesar 5\% memberikan nilai derajat substitusi yang lebih besar dibandingkan dengan konsentrasi $10 \%$ dan $15 \%$. Ketika konsentrasinya tinggi justru gugus asetilnya berkurang.

Menurut Amalia dkk (2016), penambahan asam asetat (di atas 12\%) akan menyebabkan DS tepung kentang menjadi berkurang. Hal ini disebabkan karena terjadi hidrolisis tepung atau reaksi eliminasi yang menghasilkan air (dari tepung dan produk samping esterifikasi) yang tidak dibuang dari reaktor selama reaksi berlangsung.

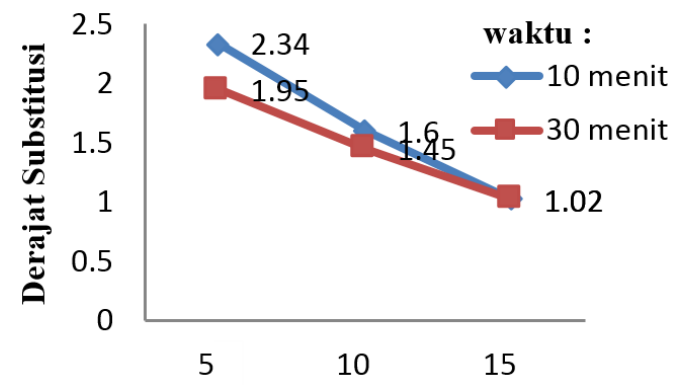

Konsentrasi (\%)

Gambar 1. Kurva Pengaruh Waktu dan Konsentrasi Asam Asetat terhadap Derajat Substitusi pada suhu $55^{\circ} \mathrm{C}$.

Uji derajat substitusi jika dilihat dari pengaruh waktu reaksi memperlihatkan bahwa semakin lama waktu reaksi, maka derajat substitusi (DS) semakin meningkat, hal ini karena semakin banyak gugus asetil berdifusi dan teradsorpsi pada permukaan tepung (Widiawan dkk. 2005). Kondisi ini hanya memperlihatkan peningkatan pada suhu $65^{\circ} \mathrm{C}$ dan $75^{\circ} \mathrm{C}$ saja seperti terlihat pada Gambar 2 dan Gambar 3. Peningkatan derajat substitusi pada penelitian ini tidak linier, dimana di tahap awal reaksi berlangsung cepat dan kemudian turun setelah 30 menit. Hal ini dapat dijelaskan, bahwa selama reaksi asetilasi berlangsung, situs reaktif pada molekul pati juga berkurang sebagai akibat dari modifikasi struktural molekul tepung (Amalia dkk. 2016).

Seiring dengan meningkatnya waktu reaksi, maka konsentrasi gugus asetil pada tepung asetat juga semakin berkurang. Hal ini dapat juga disebabkan karena adanya hidrolisis tepung atau reaksi eliminasi yang menghasilkan air yang tidak dibuang dari reaktor selama reaksi berlangsung (Amalia dkk. 2016).

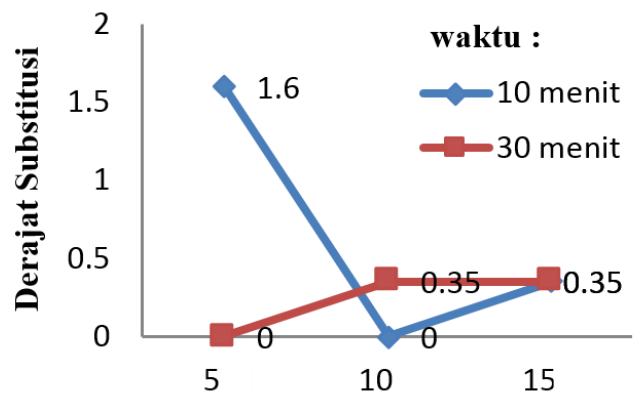

Gambar 2. Kurva Pengaruh Waktu dan Konsentrasi Asam Asetat terhadap Derajat Substitusi pada suhu $65^{\circ} \mathrm{C}$.

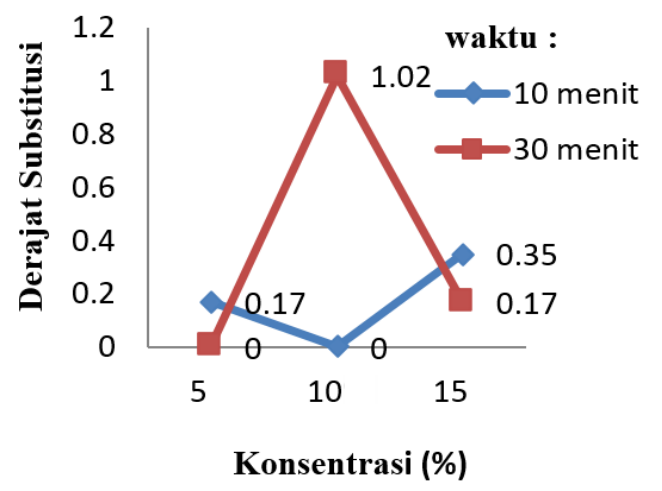

Gambar 3. Kurva Pengaruh Waktu dan Konsentrasi Asam Asetat terhadap Derajat Substitusi pada suhu $75^{\circ} \mathrm{C}$.

Suhu reaksi berpengaruh terhadap derajat substitusi, hal ini terlihat pada gambar 4 dan gambar 5 yang menunjukkan bahwa semakin tinggi suhu reaksi semakin menurun derajat substitusinya. Penurunan derajat substitusi akibat pemanasan suspensi tepung pada suhu yang semakin tinggi disebabkan kadar amilosa yang semakin tinggi atau amilopektin dalam tepung lebih rendah. Amilopektin merupakan material dengan bentuk amorf, dimana material ini merupakan daerah yang renggang dan 
kurang padat, sehingga air mudah masuk. Apabila jumlah/kadar amilopektin tepung meningkat, maka daerah amorf akan semakin luas, sehingga penyerapan air juga akan semakin besar.

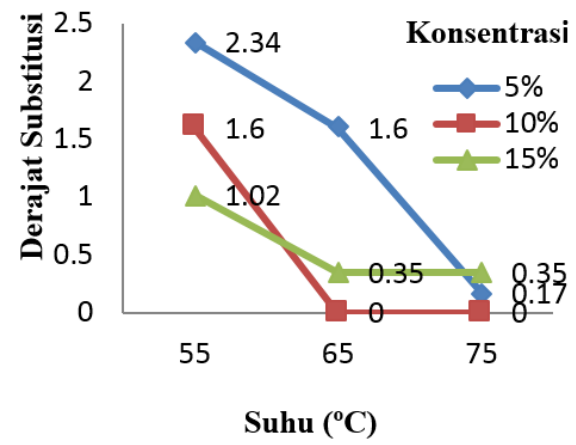

Gambar 4. Kurva Pengaruh Suhu dan Konsentrasi Asam Asetat terhadap Derajat Substitusi pada Waktu 10 menit.

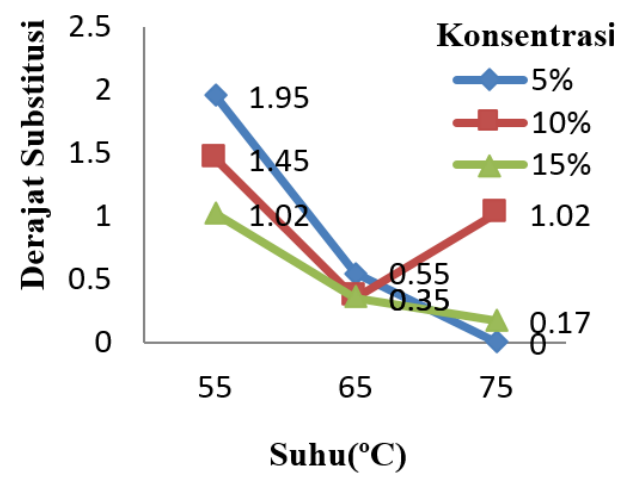

\section{Gambar 5. Kurva Pengaruh Suhu dan Konsentrasi Asam Asetat terhadap Derajat Substitusi pada Waktu 30 menit.}

\section{b. Uji Swelling Power}

Nilai swelling power tertinggi dari tepung biji nangka asetat didapatkan pada konsentrasi 5\%. Pada pembahasan sebelumnya mengenai pengaruh konsentrasi asam asetat terhadap nilai derajat substitusi, disebutkan bahwa pada konsentrasi 5\% dihasilkan tepung asetat dengan nilai derajat subtitusi yang paling tinggi dibandingkan konsentrasi $10 \%$ dan $15 \%$. Semakin besar nilai derajat substitusi berarti semakin banyak gugus asetil yang masuk ke dalam molekul tepung.

Interaksi antara molekul tepung akan menjadi berkurang ketika terjadi penggabungan gugus asetil ke dalam molekul tepung, Selain itu, akses air ke area amorf tepung akan meningkat sehingga hidrasi dan pembengkakan granula tepung juga akan meningkat (Amalia dkk. 2016).

Waktu reaksi juga berpengaruh terhadap nilai swelling power. Terlihat bahwa nilai swelling power meningkat seiring dengan peningkatan waktu reaksi. Pada pembahasan sebelumnya mengenai pengaruh waktu reaksi terhadap nilai derajat substitusi, disebutkan bahwa semakin lama waktu reaksi, maka nilai derajat substitusi (DS) semakin tinggi. Hal ini karena semakin lama reaksi, semakin banyak gugus asetil berdifusi masuk dan teradsorpsi pada permukaan tepung (Amalia dkk. 2016).

Penggabungan gugus asetil ke dalam molekul tepung dapat mengurangi interaksi diantara molekul tepung, dan dapat meningkatkan akses air ke daerah amorf pati sehingga dapat meningkatkan hidrasi dan pembengkakan pada granula tepung (Amalia dkk. 2016).

Pengaruh konsentrasi asam asetat dan pengaruh waktu reaksi terhadap nilai swelling power dapat dilihat pada Gambar 6, Gambar 7 dan Gambar 8.

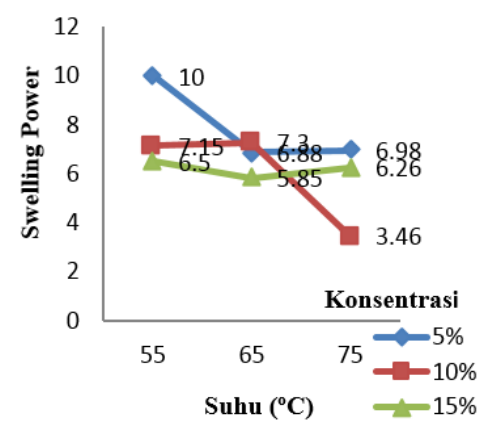

\section{Gambar 10. Kurva Pengaruh Suhu dan Konsentrasi Asam Asetat terhadap Swelling Power pada waktu 30 menit}

Daerah amorf merupakan daerah yang renggang dan kurang padat, sehingga mudah dimasuki air. Bagian amorf merupakan bagian yang lebih mudah menyerap air.

Semakin banyak amilopektin pada tepung, maka daerah amorf akan semakin luas, sehingga penyerapan air akan semakin besar. Swelling power pada tepung dipengaruhi oleh daya serap air. Semakin besar daya serap air menyebabkan swelling power meningkat.

\section{c. Uji \% Solubility}

Pengaruh konsentrasi asam asetat terhadap nilai solubility menunjukkan bahwa solubility 
tepung biji nangka akan meningkat ketika konsentrasi asam yang digunakan juga semakin besar (Widiawan dkk 2005). Hal ini dapat dilihat pada Gambar 11, Gambar 12 dan Gambar 13.

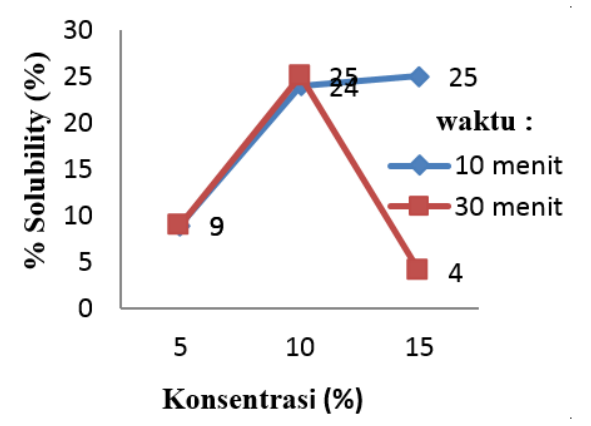

\section{Gambar11. Kurva Pengaruh Waktu dan Konsentrasi Asam Asetat terhadap \% Solubility pada Suhu $55^{\circ} \mathrm{C}$.}

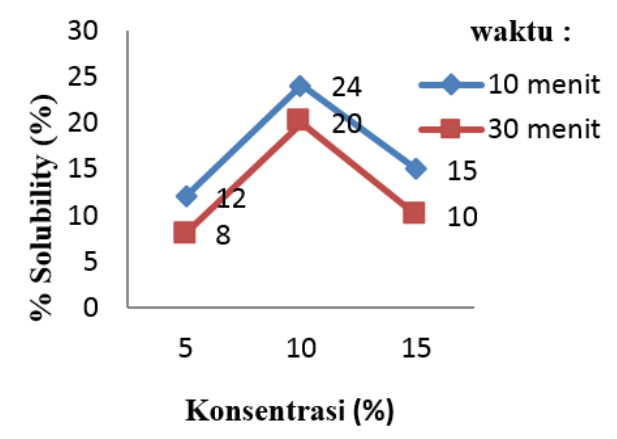

Gambar12. Kurva Pengaruh Waktu dan Konsentrasi Asam Asetat terhadap \% Solubility pada Suhu $65^{\circ} \mathrm{C}$.

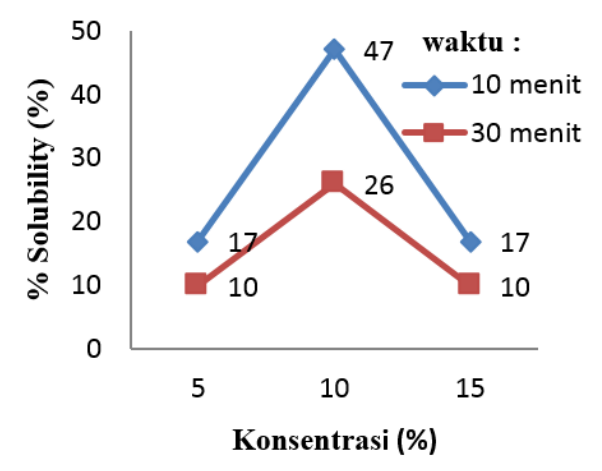

Gambar 13. Kurva Pengaruh Waktu dan Konsentrasi Asam Asetat terhadap \% Solubility pada Suhu $75^{\circ} \mathrm{C}$.
Substitusi gugus asetil pada tepung biji nangka berpotensi melemahkan ikatan hidrogen yang ada di molekul tepung sehingga amiloasa akan keluar dari granula, dan mengakibatkan peningkatan nilai solubility tepung asetat. Pada pembahasan sebelumnya pengaruh konsentrasi terhadap derajat substitusi, pada konsentrasi 5\% dihasilkan pati asetat dengan nilai derajat subtitusi yang paling tinggi dibandingkan konsentrasi $10 \%$ dan $15 \%$.

Semakin tinggi nilai derajat substitusi, maka jumlah gugus hidroksil yang tersubstitusi juga semakin meningkat. Hal ini mengakibatkan peningkatan sifat hidrofobik (tidak suka air) dari tepung yang pada akhirnya akan mengurangi kelarutan tepung di dalam air. Dalam penelitian ini, pada konsentrasi 5\% (dengan nilai derajat substitusi paling besar) memiliki nilai solubility yang rata-rata lebih kecil dibandingkan konsentrasi 10\% dan 15\%

Pengaruh waktu reaksi terhadap nilai solubility menunjukkan bahwa pada konsentrasi asam asetat sebesar 5\%, 10\% dan $15 \%$, semakin lama waktu reaksi, maka nilai solubility semakin menurun. Hal ini dipengaruhi oleh semakin besarnya \% Asetil dan derajat substitusi (DS).

Substitusi gugus asetil pada tepung gadung juga terbukti dapat melemahkan ikatan hidrogen pada molekul tepung sehingga air lebih mudah berpenetrasi ke dalam granula tepung dan menyebabkan keluarnya amilosa dari granula. Inilah yang menyebabkan nilai solubility semakin meningkat.

Pada Gambar 14 dan 15 dapat dilihat bahwa solubility tepung biji nangka asetat mengalami peningkatan setiap ada kenaikan suhu pemanasan. Kelarutan tepung yang semakin meningkat akibat pemanasan suspensi tepung yang semakin tinggi disebabkan amilosa telah mengalami depolimerisasi. 


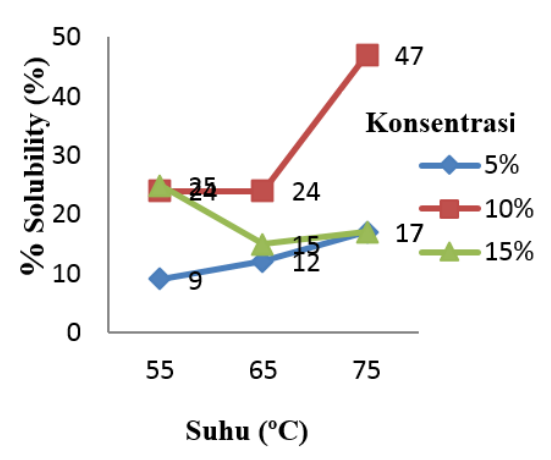

\section{Gambar 14. Kurva Grafik Pengaruh suhu dan konsentrasi asam asetat terhadap \% solubility pada suhu waktu 10 menit.}

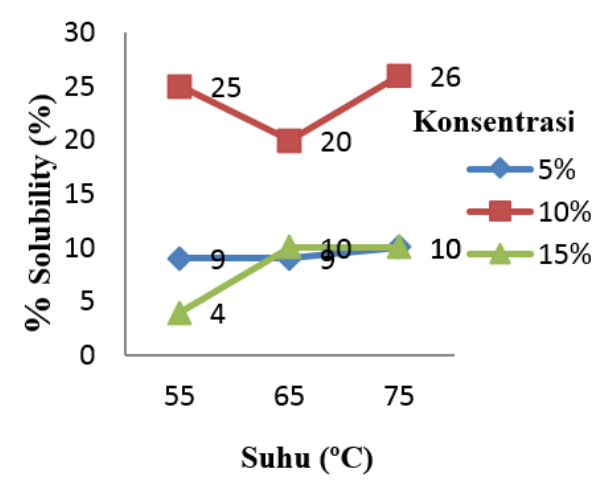

\section{Gambar 15. Kurva Pengaruh suhu dan konsentrasi asam asetat terhadap \% solubility pada suhu waktu 30 menit.}

\section{KESIMPULAN}

Modifikasi tepung biji nangka dengan menggunakan metode asetilasi asam asetat menunjukkan bahwa kondisi optimal diperoleh pada tepung yang dimodifikasi dengan konsentrasi $5 \%$, suhu $55^{\circ} \mathrm{C}$, dan waktu reaksi 10 menit, dengan nilai swelling power, solubility, dan derajat substitusi sebesar 7,40 g/g; $9 \%$; dan 2,34 karena setara dengan tepung terigu dengan kisaran swelling power antar 7,30 - 8,40 $\mathrm{g} / \mathrm{g}$.

\section{DAFTAR PUSTAKA}

Hakkim, Azafilmi., Faresti Sistihapsari, 2015, Modifikasi Fisik Kimia Tepung Sorgum Berdasarkan Karakteristik Sifat Fisiko Kimia Sebagai Substituen Tepung
Gandum, Fakultas Teknik, Universitas Diponegoro, Semarang.

Astuti, Farida Kusuma., dan Yuli Arif Tribudi. 2017. Penambahan Pati Biji Nangka (Artocarpus heterophyllus lamk) Terhadap Kualitas Kimia Bakso Ayam, Jurnal Teknologi Pertanian, Vol.8, No.2, Desember 2017, Hal.33-39, Pontianak.

Ibrahim, Halim.,Lilik Eka Radiati dan Imam Thohari, 2014. Pengaruh Penambahan Pati Biji Nangka (Artocarpus heterophyllus lamk) Terhadap Kualitas Fisik Nugget Ayam, Jurnal, Fakultas Peternakan, Universitas Brawijaya, Malang.

Amalia, Rizka., dan Andri Cahyo Kumoro, 2016, Analisa Sifat Fisikokimia dan Uji Korelasi Regresi Antara Nilai Derajat Substitusi dengan Swelling Power dan Solubility pada Tepung Gadung (Dioscorea hispida Dennst) Terasetilasi, Jurnal Inovasi Teknik Kimia, Vol.1, No.1, April 2016, Hal.17-26, Semarang.

Ma'rufah, Asvif., DKK, 2016, Pengaruh Modifikasi Secara Enzimatis

Menggunakan Enzim $\alpha$-Amilase dari Kecambah Kacang Hijau Terhadap Karakteristik Tepung Biji Nangka (Artocarpus heterophyllus lamk), Jurnal Inovasi Teknik Kimia, Vol.1, No.2, Oktober 2016, Hal.65-70, Semarang.

Rohmah, Miftakhur., 2013, Kajian Kandungan Pati Amilosa dan Amilopektin Tepung dan Pati pada Beberapa Kultivar Pisang (Musa spp), Fakultar Pertanian, Universitas Mulawarman, .

Palupi, Hapsari Titi., 2012, Karakteristik Pati Resistan dari Pati Jagung Termodifikasi Asetat, Jurnal Teknologi Pangan, Vol.3, No.1, Juni2012, Hal.13-28, Pasuruan.

Kurniawati, Indah., 2015, Karakteristik Maltodekstrin dengan Hidrolisis Enzim $\alpha$-Amilase, Jurnal Provesi, Vol.13, No.1, September 2015, Hal.47-51, Surakarta.

F,Parwiyanti., Pratama.A., Wijaya.N., Malahayati., dan E.Lidiasari, 2011, Swelling Power dan Kelarutan Pati Ganyong (Canna edulis Kerr.) Termodifikasi Melalui Heat-Moisture Treatment dan Penambahan Gum Xanthan untuk Produk Roti, Fakultas Pertanian, Universitas Sriwijaya, Palembang. 
Widiawan, I Made Edi., K.A.Nocianitri., dan Nengah Kencana Putra, 2005, Karakteristik Sifat Fisiko-Kimia Pati Talas Kimpul (Xanthosoma Saginifolium) Termodifikasi dengan Metode Asetilasi, widiawanedy @yahoo.co.id.

Sari, Kartining Tyas Permana., 2012, Pemanfaatan Tepung Biji Nangka (Artocarpus heterophyllus lamk) Sebagai Substitusi dalam Pembuatan Kudapan Berbahan Dasar PNT pada Balita, Skripsi, Jurusan Ilmu Kesehatan Masyarakat, Fakultas Ilmu Keolahragaan, Universitas Negeri Semarang, Semarang. 